\title{
Anthrovision
}

Vaneasa Online Journal

$6.2 \mid 2018$

Visual Anthropology From Latin America

\section{Counter Narratives}

Visual Anthropology and 'Memory Activism' in Peru

Martha-Cecilia Dietrich and María Eugenia Ulfe

\section{(2) OpenEdition \\ 1 Journals}

Electronic version

URL: http://journals.openedition.org/anthrovision/3725

DOI: 10.4000 /anthrovision.3725

ISSN: 2198-6754

Publisher

VANEASA - Visual Anthropology Network of European Association of Social Anthropologists

\section{Electronic reference}

Martha-Cecilia Dietrich and María Eugenia Ulfe, " Counter Narratives », Anthrovision [Online], 6.2 | 2018,

Online since 31 December 2018, connection on 04 September 2019. URL : http://

journals.openedition.org/anthrovision/3725; DOI : 10.4000/anthrovision.3725

This text was automatically generated on 4 September 2019.

(c) Anthrovision 


\title{
Counter Narratives
}

\author{
Visual Anthropology and 'Memory Activism' in Peru
}

Martha-Cecilia Dietrich and María Eugenia Ulfe

\section{Waking the Sleeping Beauty}

1 Carlos Ivan Degregori and Pablo Sandoval (2009) once referred to Peruvian social anthropology as a sleeping beauty that - in its current state - could only be described as 'fragmented, exclusive, unequal, abandoned, prejudiced and distrustful' (151). Analysing its development during the second half of the twentieth century, they identified neoliberal modernisation as one of the main causes of this situation. In the 1940s and 1950s, public universities were highly productive academic institutions with established international ties and support. During the years of military rule, from the late 1960s until the 1970s, universities experienced a sudden drop in public spending and an increasing political radicalisation of staff and students, which led to a mass migration of lecturers from public educational institutions to NGOs and the private sector (Degregori and Sandoval 2009: 91). Institutional and curricular adjustments to the lack of resources, increasing privatisation, and continuing social inequalities in accessing education were the results of more than three decades of political instability. President Alberto Fujimori (1990-2000) introduced neoliberal policies to the educational sector, hand in hand with a brutal retaking of political power and control over universities, which together consolidated an authoritarian project that would be termed 'academic modernization' (Degregori and Sandoval 2009: 101). Despite institutional setbacks, social sciences in general, and social anthropology in particular have mirrored the radical social transformation that occurred in the country due to political violence, neoliberal policies, and the emergence of indigenous politics. These developments have shaped research in Peruvian anthropology, which continues to constitute an academic community of critical thinkers who are deeply involved in the social and political realities of the country. Degregori and Sandoval (2009: 155-163) conclude that by defying myths that divide the academic community into Lima and 'the rest' of the country, promoting critical debates, 
forging international ties, and participating in the democratisation of such institutions, the sleeping beauty can be awoken. We are convinced that this process has begun.

There is more to say about the highly politicised institutional landscape of Peruvian academia, the gaps between private and public universities, and the kinds of research projects that receive institutional support and have access to resources, but for the purpose of this article, we only focus on the place of visual anthropology within a community of people and ideas that are inevitably shaped by their socio-political environments and engagements.

3 Peruvian visual anthropology has its institutional home exclusively at the private Pontificia Universidad Católica del Perú (PUCP), which is considered one of the leading universities in the country, particularly in social science research (Arispe-Bazán 2016). Created in 2009 by Gisela Cánepa and Alonso Quinteros, the MA programme in Visual Anthropology is staffed by lecturers who were initially trained in audio-visual methods as part of the Institute for Ethnomusicology. ${ }^{1}$ With its four core areas of research ethnographic films; media and technology; art, memory and material culture; performance and sensory anthropology ${ }^{2}$ - this program opened a space for experimentation in audio-visual methodology and theory seeking to explore visual imagination and culture in contemporary Peru (Cánepa 2011). Graduates of the programme have set up individual courses and workshops on how to incorporate visual anthropology in curricula, for instance at anthropology departments at Universidad Nacional San Antonio de Abad in Cusco and Universidad Nacional de San Augustin in Arequipa. However, a prevailing shortage of researchers and resources makes an ongoing establishment of programmes difficult. Despite the increasing accessibility of media technology, production processes -whether for films, sound, or photographic projects require an extended infrastructure and continuous financial support for the works to meet the production values required for international film festivals and other media platforms. Nonetheless, practitioners situated in different academic institutions in the country are working to establish local platforms and audiences that can stimulate a continuous dialogue. Furthermore, they have creatively and meaningfully incorporated audio-visual methods and theory into their works, some of which we have included here.

Peruvian social anthropology is very much focussed on socio-political issues in the country, which are not too dissimilar to those of other countries in the region. Prevailing research topics include social conflicts over land and exploitation of natural resources, climate change, territory and development, poverty and inequality, social and human rights movements, indigenous people's issues, popular and media cultures, as well as social memory of war and conflict, to name only a few. Here we focus on the subject of social memory, more specifically what we refer to as 'post-conflict memory' (memoria posconflicto), a research field that studies the different and often polarising ways in which people remember the Peruvian Internal Armed Conflict (1980-2000). The article will focus on the question of how the armed conflict has shaped the field of social anthropology in general and more specifically, how visual anthropology significantly contributed to a more differentiated view on methodological, aesthetic and political complexities of a past that remains contested.

5 In addition to being our own area of expertise, Memoria posconflicto is an interesting field to talk about the development of visual anthropology in Peru for two reasons. Firstly, the field has preoccupied social anthropologists since 1970 and we are therefore able to look at a large variety and continuous production of texts, images, material culture and films 
that indicate the shifting epistemological paradigms in the use of audio-visual media as means of research. Secondly, the field of post-conflict memory studies also shows how research on the narratives of violence and war has brought together three seemingly contradicting, but in our view complementary, practices: art, activism and academic reflection. In the past twenty years, anthropologists have engaged with the perspectives of victims and perpetrators of violence through diverse methodological engagements often using audio-visual technology to confront, provoke, criticize, communicate and make others engage emotionally. Using texts as well as audio-visual means to explore and articulate their findings, many authors have shown how different modes of producing knowledge not only convey different things, but also convey things differently. Anthropologists' efforts of challenging fixed narratives and official histories through the possibilities and limitations of multimodal ethnography have turned the discipline into an important field of resistance - hence the title of this article. And yet there are many nuances to this resistance that range from what can be called 'methodological activism' to more explicitly political activism, which we hope to point our readers to through the examples we have chosen for this piece. To begin our journey through the world of visual anthropology in Peru, we will explore the complexities of working in the aftermath of twenty years of violence and conflict and acknowledge how these have created the conditions for anthropologists to situate themselves at the intersection of science, art, and activism.

\section{Framing the Internal Armed Conflict}

In the late 1970s and early 1980s, Peru experienced a new 'democratic awakening' after twelve years of military rule. During the transition period from a military to a civil government, Peru's political landscape faced serious tensions. According to Alberto Gálvez Olaechea, a former member of the Tupac Amaru Revolutionary Movement, la Nueva Izquierda (the New Left) was inspired by the example of the Cuban revolution; they were convinced that every revolution started with an armed uprising, and that the country needed a revolution to break with the old ways of Peruvian politics. Gálvez Olaechea wrote, 'everything had to be redefined and discussed: new ways of how to actually do politics in a democracy, or defining what a Peruvian left actually meant' (Gálvez Olaechea 2012: 11-12). The atmosphere emanating from new guerrilla movements on the continent and Peru's deep-rooted social inequalities inspired the emergence of radical factions among left-wing parties, which later morphed into what we now know as the Peruvian Communist Party-Shining Path (PCP-SL), inspired by Maoism, and the Tupac Amaru Revolutionary Movement (MRTA), whose ideology derived from socialist ideas of the former Soviet Union.

In 1980, the Shining Path declared a 'people's war' against the Peruvian state. Based in Ayacucho and with the initial support of large factions of society, mainly from the Andean highlands, the Shining Path perceived the state as an enemy of the people, one that needed to be annihilated in order to free up space for a new order (Starn 1995; Stern 1999; Degregori 2000a, 2010). With the support of provincial teachers and teachers' unions, the Shining Path gained access to rural communities where they led campaigns to educate peasants in escuelas populares (people's schools). There they instructed communities in Marxist-Leninist-Maoist-Gonzalo thought and harnessed people's sense 
of dissatisfaction and anger at social injustice whilst still keeping a distance from other left wing and/or communist groups (Portocarrero 2012).

Four years after the Shining Path's declaration of war in 1984, the Tupac Amaru Revolutionary Movement, a more urban guerrilla group, also initiated an armed struggle against the state. In contrast with the Shining Path, the MRTA identified with the existing nation-state, but saw a need for substantial changes to it. According to their party statute from 1981, they understood socialist liberation and national equality as ideologicalpolitical solutions to a democracy permeated by social fragmentation, political repression and persecution. Their symbolic appropriation of the Peruvian flag and creation of a new national anthem signified this antagonistic relationship to the nation-state (Manrique 2014: 64). Political violence was considered a tool for achieving a global anti-imperialist project, alongside revolutionary governments like those of Cuba and other militant movements in the region, for instance the Movimiento de Izquierda Revolucionaria (MIR) in Chile, or the M-19 movement in Colombia to which they had close ties. Despite the fundamental differences between the two insurgent groups, including political vision, military strategy and (gender) ideology, politicians and mainstream media outlets have made no effort to distinguish between the two organisations, which today are remembered as mere terrorist groups. However, there is a great deal to be learned from the diversity of political organisations at the time as well as the ways their legacies have shaped today's political landscape.

9 In the twenty years of the Peruvian internal armed conflict (1980-2000), three different presidents responded to the insurgents, commanding state forces, police and clandestine paramilitary units to conduct a brutal counterinsurgency campaign that lasted until 2000 when Alberto Fujimori's increasingly autocratic and corrupt government eventually fell (Degregori 2000b; Burt 2007). With around 70,000 people killed and almost 500,000 people forced to leave their homes and migrate to the cities on the coast, the internationally acclaimed Peruvian Truth and Reconciliation Commission (PTRC) declared this conflict the longest and most costly in terms of human casualties, forced migration and material losses since the foundation of the republic in 1822 (CVR 2003, 2004). The PTRC further found state forces to be responsible for 37 per cent of the conflict's fatalities, as well as systematic human rights violations, including torture, forced disappearances, sexual violence and vandalism; however, the majority - 54 per cent - of the inflicted deaths were ascribed to the Shining Path. ${ }^{3}$ When the Shining Path started to lose control over its territories, violence was unleashed in unprecedented ways, as the PTRC's reports and many other investigations describe (Degregori 1990; Gorriti 1990; Manrique 2002; Portugal 2008, etc.). Violent punishment of civilians, public executions of so-called traitors, repression and violent control over the population, and systematic destruction of key infrastructure turned the mainly peasant population, which had initially supported the uprising, against them. Civilians, organised into self-defence committees, became key actors in the conflict through their collaboration with the Peruvian military, which ultimately led to the collapse of the Shining Path.

10 This is where the Peruvian armed conflict differs significantly from other conflicts in the region such as those in Chile, Argentina, and Brazil, where military dictatorships at the time were considered the main, if not exclusive, culprits of political persecution, forced disappearances, and extrajudicial killings. In this case, the categories of 'victims' and 'perpetrators' cannot be clearly and exclusively assigned to a specific group, whether insurgents, state forces, self-defence committees, or even individual members of civil 
society. Making and taking sides has been particularly challenging for those concerned with establishing truth and justice, similar to what Primo Levi (1989) called the 'grey zones' that exist in between categories and that carry uncomfortable, dangerous and silenced memories based on lived experiences.

While the brutality was attributed to Shining Path's messianic ideology that glorified violence and death, the effect in public discourses, particularly in centralised Lima, was to obscure and even legitimise the indiscriminate use of violence by the agents of the state. ${ }^{4}$ The complexities of the conflict, which produced victims and perpetrators on all sides, were reduced to simplified and polarised depictions of the past, often favouring the army and governments while demonising the insurgents and the people of Ayacucho who wanted social changes. This further contributed to silencing the socio-political circumstances and conditions in the country, which - according to many - led to the insurgents' public support in the first place.

\section{Crafting Pasts}

12 Seventeen years after the end of the conflict, questions of truth, justice and accountability are still very much at the centre of public as well as legal debate. The writing of the conflict's history remains contentious and the unremitting absence of some voices and perspectives in public spaces of remembrance causes a sense of exclusion from the writing of official histories. However, the emphatic circulation and distribution of competing narratives of the conflict in art, literature, films, and on various (social) media platforms critically responds to these absences and polarised depictions of the past, suggesting that memories of the armed conflict are a pressing part of the country's sociopolitical present.

The beginning of the twenty-first century not only marked a transition from a dictatorial government to a democracy but also initiated a decade of transitional justice and memory, which Degregori (2015) has described as a 'posguerra fallida', a failed post-war. With this provocative description, he criticises the state for failing to implement reforms or to initiate institutional transformations to bring solutions to the problem of social inequality, which was at the root of this conflict.

14 In academia, scholars speak of the 'era of memory' or the 'memory boom' (Basombrio 2001; Degregori and Jelin 2003; Hamann 2003; Reátegui 2012) not just in Peru but in the whole of Latin America. At the end of the twentieth century, civil societies in the region began to demand collective confrontation with their countries' violent pasts: the mass extermination of indigenous people on the continent, mass slavery during the rubber boom, and the forced disappearances of political activists and civilians during military dictatorships in the region, to only name a few. At a time when George Orwell's idea of ' alternative facts' appears to dominate political discourses, public demands for truth and justice seem more insistent than ever. Institutionalised forms of rendering violent pasts have had the difficult role of drawing political, legal, and socio-cultural dimensions of truth and justice together, a process in which scholars have served as participants and/or critical assessors. In the case of Peru, the discussion about memory, truth, and justice has taken a cultural form in the production of many different platforms, performances, and artistic repertories, even more than political scenarios and textbooks. The cultural arena is more propitious than the political terrain. However, this also shows how problematic 
the field of memory still is, as it is mainly composed of responses from civil society and contradicting state policies (Ulfe 2017a). ${ }^{5}$

Whether in truth commissions, high courts, museums, or archives, scholars and artist have created spaces for the telling of truth(s). Practitioners have looked at the circumstances and conditions in which different people involved in the events of the past have crafted and circulated these stories. However, stories that speak of perpetrators as victims, or of victims as perpetrators, have had little space for public articulation. These stories challenge simplifications and polarisations by complicating the past, not necessarily for those who live with their memories of violence and conflict, but for future generations seeking to hear different views of this shared past. The place of visual media in this process is in the field of truth-telling. Since the beginning of the conflict, people affected by the violence, artists and researchers have often resorted to cultural forms to articulate experiences of this past. As such, (audio-)visual productions such as the following examples have given creative forms of expression a political force. This force, legitimised by the claim of telling someone's very own truth, often diverges from official or popular narratives which ultimately challenge them. In the following section, we will discuss the work of the social anthropologist Olga González, who has asked uncomfortable questions about the often-contradictory and ambiguous experience of violence in an Andean community, and has incorporated audio-visual methods and materials into her approach. Even though her final work is not an audio-visual piece but a written ethnographic description, she has made evocative use of the method of visual elicitation to show the complexities of truth-telling and the use of artwork in recounting memory.

\section{From Experience to Truth: Art and Craft as Approach}

The small village of Sarhua in the Peruvian Andes is known for its local tradition of making wooden-panel paintings known as tablas. Originally, they were made to be given as gifts and for public display, and they depicted scenes of everyday life: families working in the field, harvesting crops, rearing animals, weaving textiles, family celebrations, folktales and religious events (Lemlij and Millones 2004). In the early 1990s, craftsmen and women from Sarhua went to Lima to flee the war. The Swiss journalist Peter Gaupp commissioned a group of migrant craftsmen and women to illustrate the atrocities people in their community had lived through using their traditional artistry. In Peru, art has had a long tradition as a means to contest the abuses of power by local authorities since colonial times. As early as in the seventeenth century, Guaman Poma de Ayala depicted the brutality of the Spanish conquistadors in a series of drawings that were sent as a letter to the Spanish king Felipe III to reveal the truth about his delegates' violent practices and the impacts they had on local cultures (Milton 2014: 14). ${ }^{6}$ In the context of Peru's internal war, a so-called protest art made of traditional arts and crafts has represented victims' realities since the early 1980s. According to Cynthia Milton (2014), these local cultural forms of knowledge 'give testimony to abandonment of natal lands and the disappearances of loved ones' (15). The PTRC featured such local art in relation to its final report (CVR 2003) in the form of painting and drawing contests like Yuyarisun, promoted by human rights NGOs (for instance Servicios Educativos Rurales) and photography exhibitions like Para Recordar, Yuyanapaq (2003) through which they reached nationwide recognition (Milton 2014: 15). 
17 Piraq Causa, which means 'Who is to blame?' in Quechua, is the title of the panel-set commissioned by Gaupp depicting key events and scenarios during the conflict (González 2011: 142-143). The presentation of a seemingly peaceful everyday life in the Andes are set against scenes of the Shining Path's preparation for the beginning of their armed uprising (ADAPs panels 1 and 2). The subsequent panels show acts of cruelty and corruption inflicted by local authorities and powerful villagers. One panel shows a scene where villagers illegally occupy communal lands for their personal use (panel 1, 'Enraged Comuneros'). Another panel shows sinchis (police special forces) tormenting the villagers by destroying and looting their houses, raiding their communal workshop and sexually abusing women (panels 2 and 3). Later panels show the violent arrival of the Shining Path, who locals identify as strange intruders or onqoy (meaning 'devil' in Quechua) bringing lies and false promises (panel 5). They are depicted occupying the town hall, looting stores and forcing the villagers to hold a parade on their arrival (panels 6-8). After the Shining Path's leaders kill the local authorities (panel 9), the villagers, out of fear, offer food and shelter to the insurgents, who recruit and convert old and young villagers for their fight while plundering crops and livestock (panels 12-15). Another panel shows members of the Shining Path putting 'traitors' on trial and punishing the locals on the main square (panel 16), followed by brutal interventions and deadly confrontations with state forces. Explicit scenes reveal the soldiers' methods and techniques of systematically killing villagers (panels 17-21). While some people of Sarhua act by retaliating (panel 22), others decide to leave their homes for good in search of a better life elsewhere (panel 24). ${ }^{7}$

For her research, the anthropologist Olga González brought photocopies of the tablas back to the artists' home community of Sarhua. This was her approach to elicit the villagers' memories of the violence for a further analysis of the social life during the conflict told in stories by those who stayed or returned. While the tablas support a collective claim for their truth being told to people in Lima and the world, they also reveal how the panels, in very subtle ways, articulate the social dimensions of violence in their communities. 


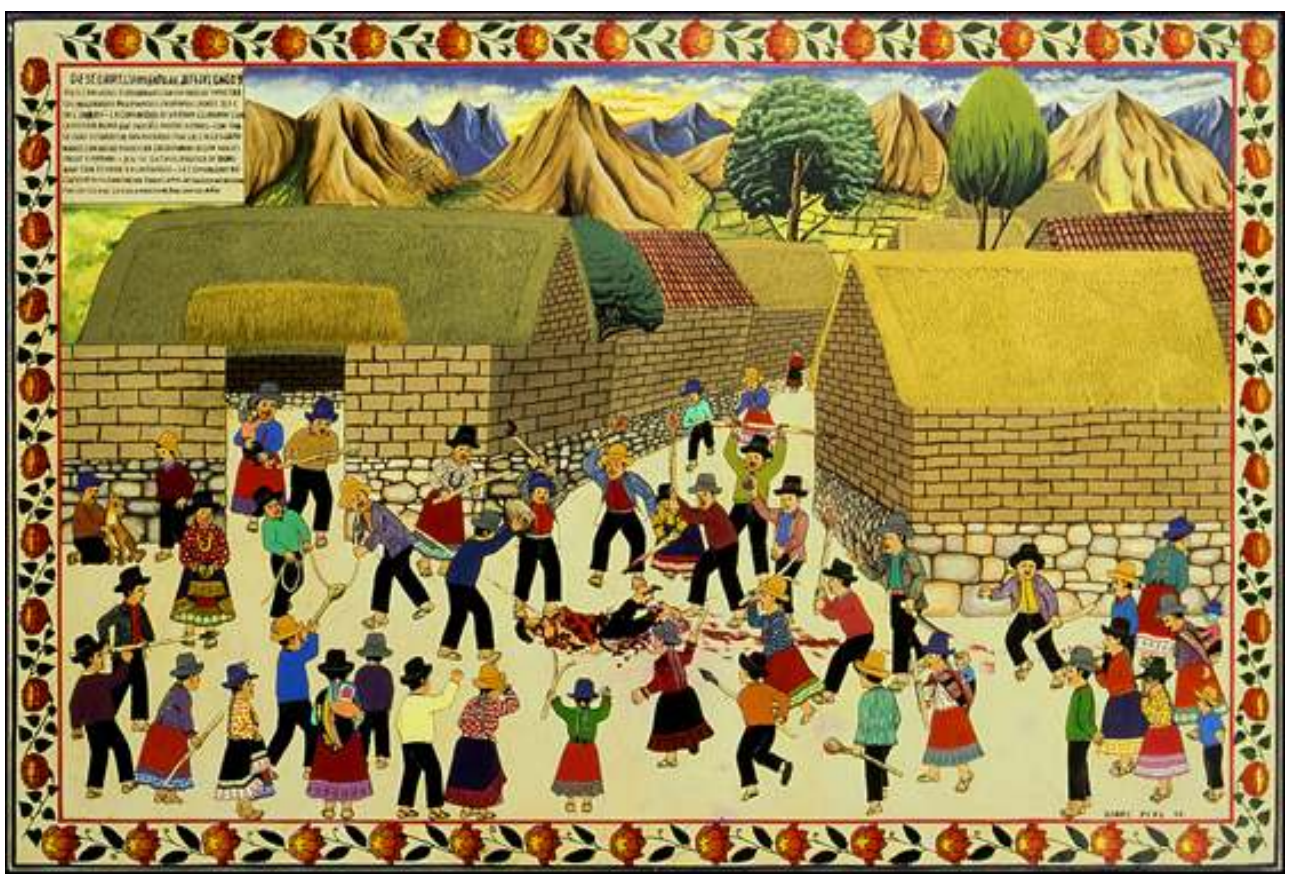

Series ¿Piraq Causa? by the Asociación de Artistas Populares de Sarhua, 1992, painting in acrylic on wood panel, 80x120cm. See Buntnix and Germana 2012

Collection: Museum of Art of Lima, courtesy of Peter Gaupp and Con/Vida- Popular Arts of the Americas. Photo: Beatrice Kuenzi (González 2011: 142-143).

The tabla above shows the leader of Shining Path being killed by the villagers of Sarhua after they turned against the insurgents. The text on the top left reads:

"Very tired and weary of the abuses and inhumane mistreatments dealt by the leader of

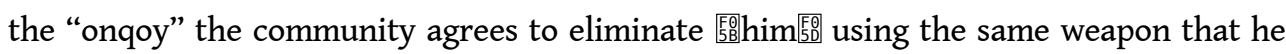
taught to kill others with so much hatred and fury. He was dragged through the streets struck with axe sickle maces spear ropes sticks and stones - thus the politics of domination through terror and force was extirpated - the community recovered its traditional organisation of Inca origin after a bitter life for many years'. (translated version in González 2011: 142)

The text suggests a particular reading of the picture: the villagers standing up against the ultimate aggressor (the devil). Alternatively, it can be read as a group of people collectively killing a man. But who is this man? In her book, González follows the tangled thread of the village's public secret, which is the killing of Narciso Huicho, a man from the community and his murderers, neighbours and relatives. In small communities like Sarhua, neighbours turned into enemies, which underlines the social complexity of violence that unfolded during the conflict. Drawing on extensive fieldwork and using the panels not to depict but to explore what happened, González examines the relationship between secrecy and memory through the images. By paying attention to the gaps and silences within both the Sarhuinos' oral histories and the panels, she reveals the pervasive reality of secrecy for people who have endured episodes of intense violence. These kinds of depictions appeal to realism to show "what had happened" in their village. Explicating one panel after another in close conversations with the villagers, she reveals how public secrets turn the process of unmasking into a complex mode of truth telling. 
Ultimately, she argues that public secrecy is an intricate way of 'remembering to forget', one that establishes a normative truth that makes life liveable in the aftermath of a civil war. The tabla is a kind of testimonial art similar to the retablo, which is another art-form from Ayacucho that has been used to articulate experiences of violence.

\section{Scenes of the Unspeakable in the Peruvian retablo}

The artist and anthropologist Edilberto Jimenez Quispe comes from a long line of painters and retablo artists in Ayacucho. Retablos are wooden frames, the size of little puppet houses, in which scenes are depicted using small figurines. Initially, they exclusively depicted celestial subjects, but later, local artists divided the space. Cut horizontally in two, the upper level is dedicated to the spiritual world while the bottom level depicts the world of humans and nature. In this sense, retablos allow us to explore how the world is interpreted and organised in Andean cosmology (Golte and Pajuelo 2012; Ulfe 2014).

In his book, Jimenez (2010) tells the story of how he was responsible for a radio programme that transmitted Huaynos and other songs from different parts of Ayacucho during the conflict. In 1996, he travelled to Chungui with the Centro de Desarollo Agropecuario-Ayacucho ${ }^{8}$ to collect songs and testimonies of villagers. What he found were communities deeply wounded by the conflict and forgotten by the government. He began to draw those stories in collaboration with the villagers over nightly fires.

Book cover for Chungui. Violencia y Trazos de Memoria

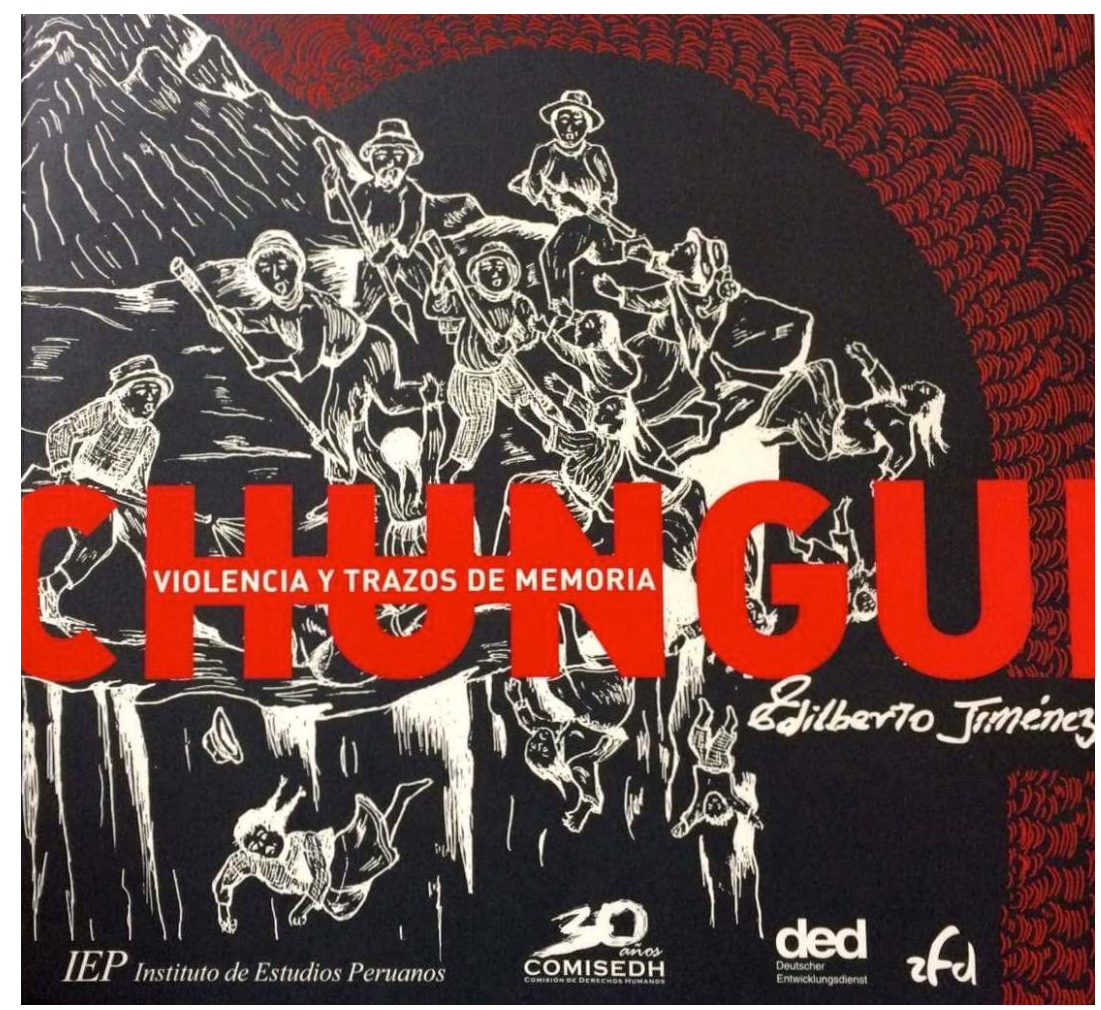

Written by Ediberto Jimenez

Instituto de Estudios Peruanos Instituto de Estudios Peruanos 

incorporate those stories into their research practices and analyses. However, the circumstances and conditions of telling stories about Peru's most recent violent past have also opened up new areas of silence that - perhaps more than ever - prevent Peruvian society from coming to terms with its past. Social anthropologists have become increasingly aware of these other silent memories. In studies conducted with former insurgents, researchers have found that many people articulate a strong sense of injustice in relation to the official history of the conflict (Dietrich 2015; Gamundi 2010; Theidon 2010; Valenzuela 2011). To them, sharing their experiences publicly is a way to contest institutional silences that aim to reproduce and secure a hegemonic truth and memory of the conflict. Insurgents are not the only ones who hold this critical opinion. Pepe Garrido, a military general during the conflict, stated in an interview that 'the right to memory has been hijacked by human rights activists' (Lima, 28.02.2012 in Dietrich 2015). The concept of the 'right to remembrance' was indeed one that initially appeared with the human rights movement at a time when the truth and memory of the conflict was a demand from civil society (Basombrío 2001). With the 'right to remembrance', human rights activists appealed to the constitutional state to reconstruct a past that would recognise and thereby bring justice to the victims of the conflict. At the same time, members of state forces refused to talk to researchers in order to protect the institution they had worked for and for fear of the legal consequences of revealing sensitive information. Insurgents, particularly those in prison, on the other hand, were suspicious and therefore cautious about how their testimonies would be used. 

justice for the victims of the conflict and should catalyse a process of social healing. But this 'right to memory' reserved for victim-survivors, as some insurgents and members of the military assert, is not theirs to claim for their involvement in causing violence. For this reason, stories that do not fit neatly into the victim category have been told in a variety of films. In fact, film has been a key medium to express memories and perspectives that diverge from the mainstream. As with the films discussed here, which are made by or in collaboration with social anthropologists, they share the intention to extend categories of eligibility to claim truth and justice.

Since the end of the conflict, social anthropologists have tapped into an already existing 'memory genre', using filmmaking either to support the people they were conducting research with (see the examples of Bernedo, Degregori, and Soto discussed below) or as an explorative means to further their understanding of the experiences of violence and conflict (see the examples of Gálvez, Cárdenas, Robin, and Dietrich discussed below). Nonfiction filmmaking has had a constant presence during the conflict as well as in its aftermath, but the focus and engagement with the conflict have shifted considerably in the last three decades. While governments in Lima initially treated the insurgency and its subversive violent actions more like hinterland incidents that were hardly worth media coverage (Aguirre and Walker 2017: 223), journalists became increasingly aware of the serious threat brewing in the Andes, risking their lives to shed light on the atrocities being committed. When a group of eight journalists, who were accompanied by two local guides, were brutally murdered by members of the community of Uchuraccay, an investigative commission led by the Nobel prize-winning writer Mario Vargas Llosa declared that the murders were a tragic accident, committed only because the locals had confused the visitors with insurgents and their cameras with weapons (CVR V: 121). This story became a cautionary tale for other journalists. For security reasons, journalists were not allowed to report directly or else would be at major risk of being killed or disappeared (as happened to the journalists Hugo Bustíos and Jaime Ayala). Journalists therefore relied almost exclusively on the information provided by the members of the armed forces and federal police who supported the commission's declarations. However, later investigations revealed that sinchis or paramilitary forces may have been present during the murders of the journalists. Suspicion arose that the military may have been complicit in the crimes of Uchuraccay at a time when state forces had mounted a strong military offensive in Ayacucho and adjacent regions (Del Pino 2003, 2017; Tipe and Tipe 2015) and it is one explanation as to why films about the conflict were initially predominantly fictional. ${ }^{9}$

While journalists and scholars during the conflict and shortly after were concerned with revealing the truth of what had actually happened in the Andes, non-fiction films made after the conflict began to reflect on how people were learning to come to terms with their experiences. Such documentary films include Alias Alejandro (2005) by Alejandro Cárdenas, and Lucanamarca (2008) by Héctor Gálvez. Director Cárdenas is the son of an MRTA leader, Peter Cárdenas Shulte, and the film deals with his journey to meet his father who was sentenced to twenty-five years in prison. Alias Alejandro is a testimonial film that brings the story of Peter's sons, ex-wife, and relatives who went into exile, to the forefront. It is a coming-to-terms movie in which the images of the encounter between Alejandro and his father are animated drawings. The combination of these two forms of storytelling gives a sense of realism and, in a way, veracity to the film. ${ }^{10}$ Meanwhile, 
Lucanamarca is about a broken community in the highlands of Ayacucho that seeks to mourn the death of their members, though divisions between sides continue to stand in the way of sharing pain and suffering. These are early examples of how historical approaches to understanding the conflict $^{11}$ turned into more personalised forms of storytelling.

Film poster for Alias Alejandro (2005)

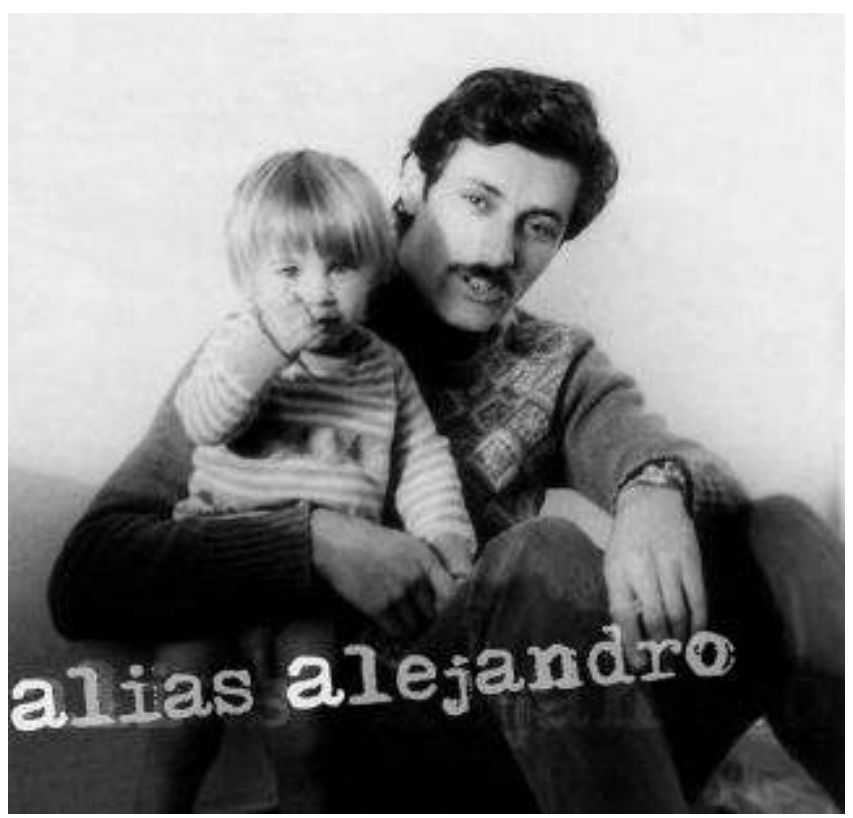

Directed by Alejandro Cardenas. Courtesy of the director

Film poster for Lucanamarca (2008)

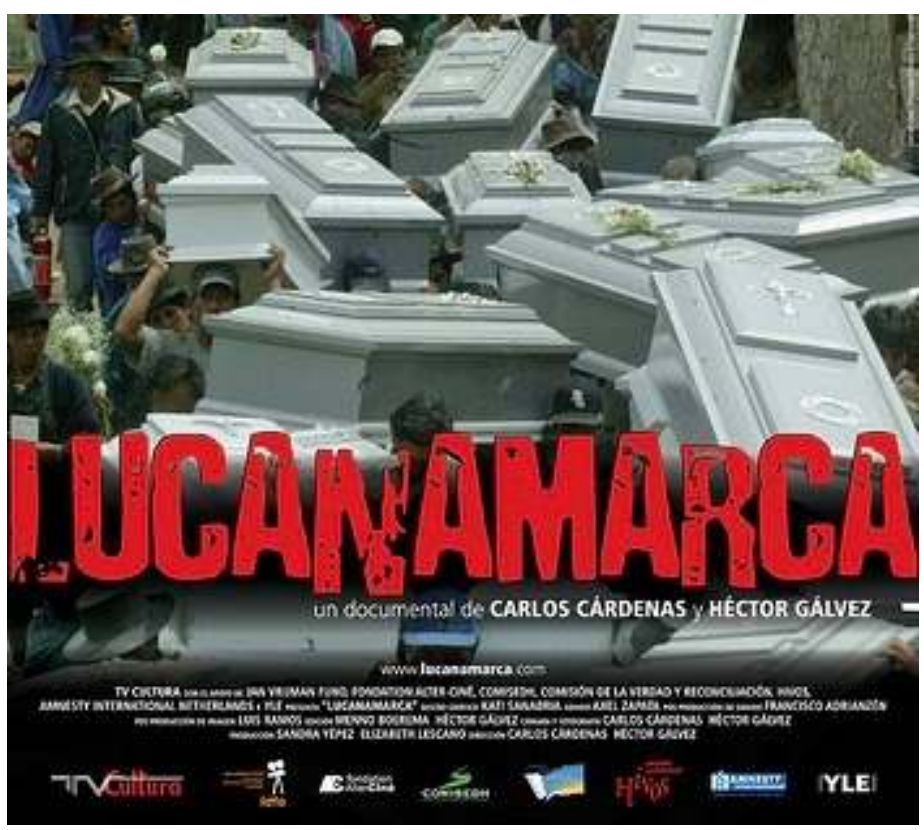

Directed by Héctor Gálvez. Courtesy of the director 
Social anthropologist Karen Bernedo, who was one of the first to complete the master's program in visual anthropology at the PUCP, made her debut audio-visual contribution with almost no funding. Tránsito a la Memoria (2005) is a short film and, as she explains in its description, a homage to the women who were victims of violence. She turned this audio-visual project into her Master thesis entitled Mamaquilla, Hilos (des) bordados de la Guerra (Bernedo 2011), in which she follows a group of internally displaced women living on the outskirts of Lima. These women are not only brought together by their past but also by their struggles for the lands they currently occupy. Sharing a passion for weaving, they put their sorrows into careful arrangement of cloths and threads. The film explores these women's narratives through interviews interwoven with images of their collective crafting. It also situates their stories in a contemporary context by bringing in the current struggles they face to own a home. Bernedo describes herself as a director and social activist, emphasising the agenda of her works, which is to combine research with active memory work (Malek 2015: 54). She is currently preparing a documentary video based on the enactments of the horrific events in Accomarca. ${ }^{12}$

Film poster Mama Quilla: Los hilos bordados de la guerra (2011)

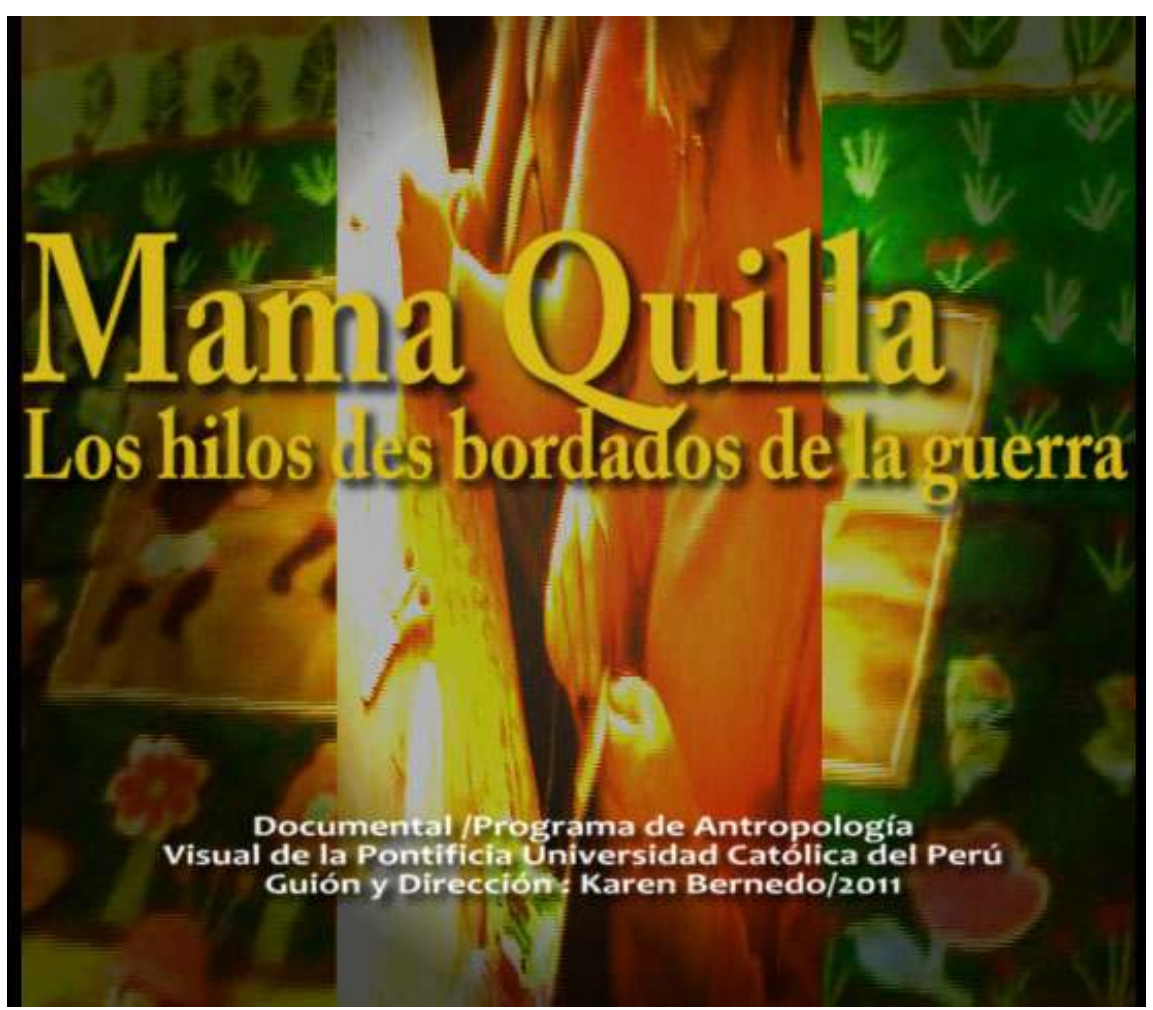

Directed by Karen Bernedo. Courtesy of the director

31 Valerie Robin Azevedo, a social anthropologist at the University of Paris, collaborated with Nicolas Touboul to make Sur le Sentiers de la Violence (2007), which compares the different memories of two communities: Cceraocro and Huancapi. The filmmakers' intervention is kept to a minimum while narrators' part is long and extended. This allows viewers to come close to the narrators' stories, their voices and the expressions on their faces. The film leaves viewers with a very sensorial impression, even though the narrated stories seem to have been carefully curated in the editing. The film reflects the complexities and ambiguities of communities with different stories and collective 
histories in-the-making. It explores the traumas left by the conflict and how traditional ritual practices are being adapted to integrate into the present realities of these communities.

DVD cover of Sur les Sentiers de la Violence (2007)

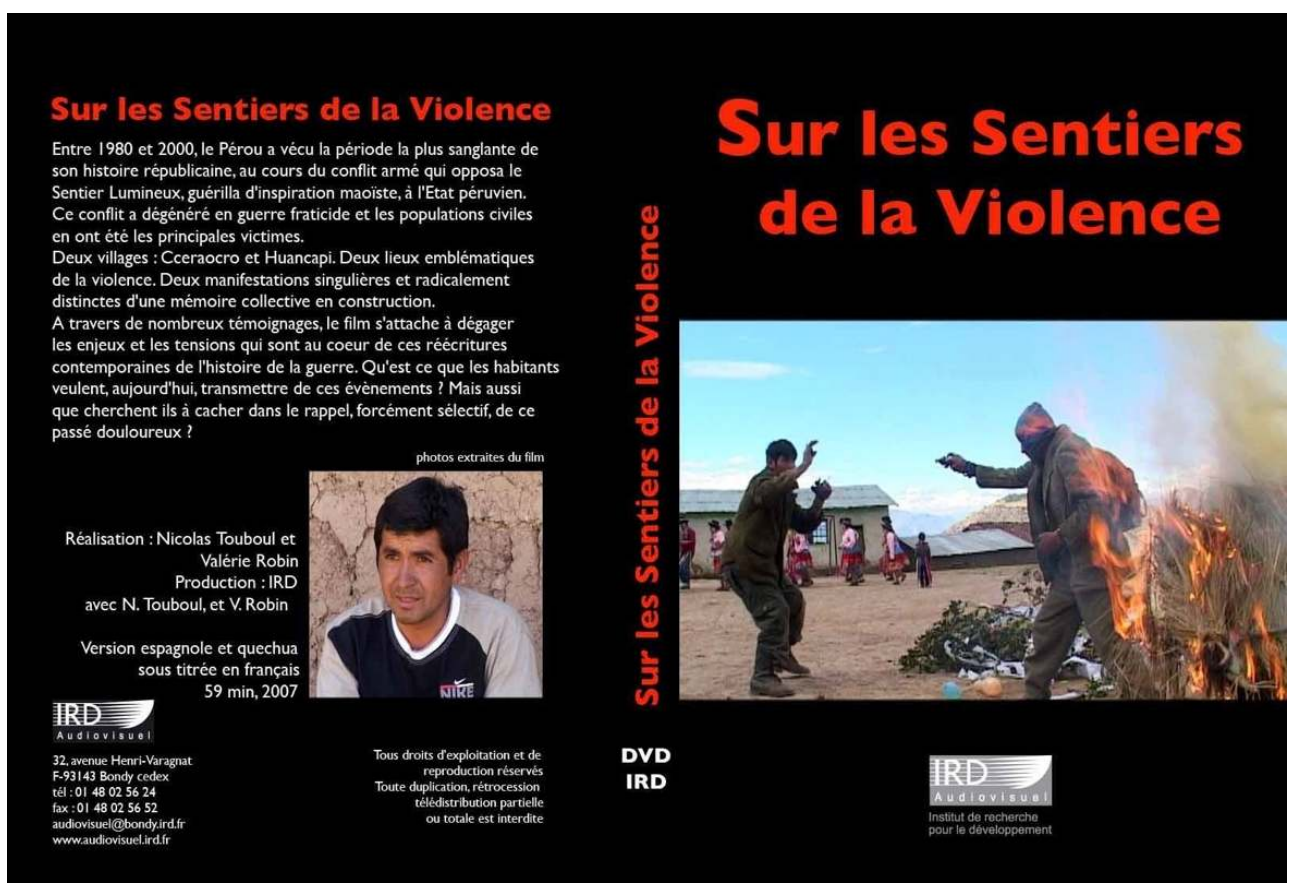

Directed by Valerie Robin. Courtesy of the director

These and other documentaries made by or in collaboration with (visual) anthropologists underline the existence of stories that are distinct from the black-and-white polarisations that are so prominent in public discourses. They are about people who, to protect their families or escape political persecution, moved between different sides of the conflict or covered up with which side they had allied themselves. People in conflict zones negotiated their survival and well-being with those who supported insurgency and with those who fought against it. When and with whom to speak and what to say were subject to careful consideration, sometimes leading to the rupture of family and social structures as well as community life. These tensions are reflected in the stories told in these documentaries.

In my own film, Entre Memorias (Dietrich 2015), I investigate practices of remembering the Peruvian internal armed conflict and how the narration of memory shapes the contemporary social, political, and personal lives of those considered victims and perpetrators. It is an audio-visual as well as textual ethnography of narratives and rhetorical strategies and the different sites, stages, and templates upon which memory is formed. I invite relatives of disappeared female insurgents in prison and members of state forces to make a film that reflects their notions of this contested past. In this project, I understand filmmaking as a mode of producing knowledge both ethnographically as well as analytically on how participants narrate their experiences and 'make memory' in post-conflict Peru. The documentary has three collaboratively made audio-visual pieces that aim to create a dialogue among disparate memories, the attainment of which remains elusive. 


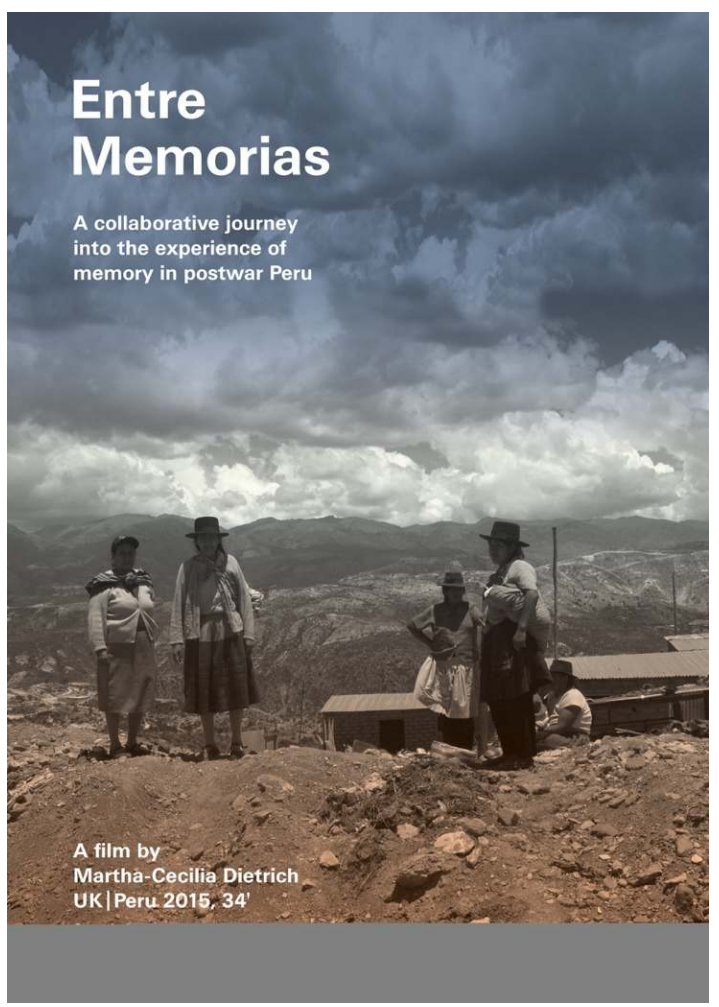

Directed by Martha-Cecilia Dietrich. Courtesy of the director

The final film we discuss, Caminantes de la Memoria (2015) by the social anthropologist and self-taught filmmaker Heeder Soto, is a moving piece in which the filmmaker positions himself as the main character and relates his own story of horror, including the loss of his father to the conflict. His film is a precise and dedicated homage to the women of Anfasep, the oldest victims' organisation in the country. ${ }^{13}$ We selected this film because Heeder speaks to the people that are close to or part of his own history and life. Next to Robin's film, this is one of the few works which is mainly Quechua and in which its characters trustfully open themselves up to the filmmaker. It touches upon the difficult experience of violence through personal narratives and incorporates the subjects of extreme poverty and indifference that permeate the conflict and its aftermath. It is an attempt to understand the diversity of voices brought together by the film-maker Heeder Soto who notably shares his protagonists' experiences. 


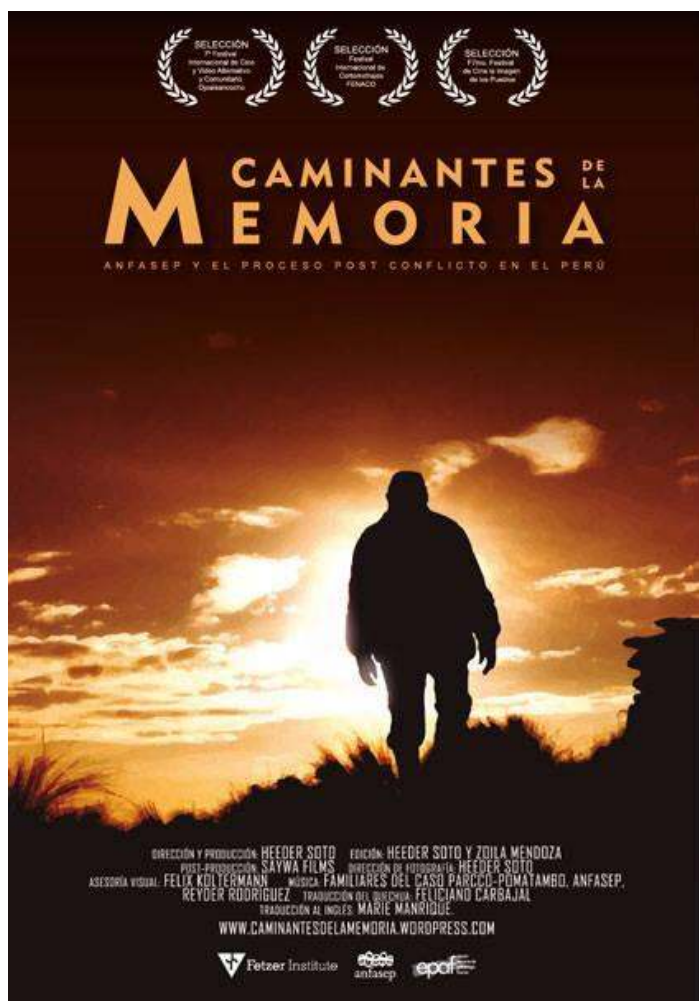

Directed by Heeder Soto. Courtesy of the director

\section{On Social Anthropology and Activism}

Social anthropological research and memory activism in Peru cannot be seen as separate fields. The socio-political situation of the country, given its history of violence and conflict, has had a profound impact on today's researchers. In fact, memory studies have become a field on its own. The Masters Programme in visual anthropology at the PUCP offers a line of research dedicated to art, material culture, and memory. Audio-visual research in Peru is certainly much more than memory activism, but memory activism is, nonetheless, one of the strongest motivations for the making of audio-visual anthropological artefacts. Despite the diversity of fields and audio-visual methodologies used by researchers from and in Peru, our concern here is specifically with memory activism because it is a consolidated field that bridges audio-visual academic practices and political attempts to work out the myriad of truth-telling that emerges in times of war and after.

During our 2017 RAI film festival panel, Trends in Ethnographic Filmmaking in Latin America, from which the initiative for this special issue arose, the panellists critiqued the festival's film programming since out of 44 films selected, none was made by a Latin American filmmaker. Indeed, most of the films screened were produced in Europe or the United States, even though people and places in the films were from elsewhere. However, it was clear from the catalogue of film submissions that the problem was not a lack of films submitted by Latin American filmmakers. Some argued that a jury of eleven allwhite, mostly male judges, many of whom have a background in the mainstream 
documentary film industry, favoured a more Western gaze in terms of format, aesthetic and narrative styles that were expressed in the programming. ${ }^{14}$ Others argued that the films submitted may have simply not been 'good enough' in terms of production values or that they may have been 'too political' for an audience of European social anthropologists. The latter we found an intriguing commentary, since many of the films produced by or in collaboration with anthropologists in Latin America take a highly political, if not activist, stance. So, what exactly could be the point of divergence?

In our research for this piece, we stumbled across an article written by Penny Harvey in 1993 that discusses the relationship of anthropological interest in cultural differences from local (indigenous) politics. Even though the discussion here is not about the gap that separates social anthropology from indigenous politics but about the diverging directions of ethnographic filmmaking practices in Europe and Latin America, there are similarities in the arguments. Harvey asserts that the differences between 'local' filmmaking and ethnographic filmmaking lie in the epistemological meanings attributed to the practices and agendas of particular kinds of filmmaking. The important question is whether an anthropological commitment to incommensurability, one that 'acknowledges that cultural difference is not merely the difference of political interest, can simultaneously sustain/contain any kind of political commitment' (Harvey 1993: 164). The antagonistic relationship between anthropological endeavours and political commitment, as Harvey concludes, is the result of differing political semiotics of representation and articulation following differing epistemological imperatives.

However, it seems to us that the argument could be taken further and beyond semiotics of representation and epistemological interests. Social anthropology in Latin America in general, and in Peru specifically, has been very much connected to, if not to say actively engaged in, the processes of nation building, in search for a national 'character' or identity as well as in the critique of national/political projects which are very much influenced by historical power relationships and geopolitics. What it means to be a social anthropologist in Latin America and in other post-colonial regions of the world is very much associated with being politically committed. Perhaps the divergence starts with answering the question of what is the political. However, the works we chose to discuss here hopefully give a sense of the manifold ways that audio-visual research has been inspired by local visual and political cultures, shaping and complicating discourses about memory in post-conflict Peru.

\section{BIBLIOGRAPHY}

\section{Books and articles}

Aguirre, Carlos and Charles F. Walker. 2017. The Lima Reader: History, Culture, Politics. Durham London: Duke University Press. 
Arispe-Bazán, Diego. 2016. The Making of a Visual Anthropology Program: An Interview with Gisela Cánepa and María Eugenia Ulfe, Pontificia Universidad Católica del Perú. American Anthropologist 118(1):172-175.

Basombrío, Ernesto de la Jara. 2001. Memoria y batallas en nombre de los inocentes. In PERÚ: 1992-2001, Special issue, Revista Ideele. Lima: Instituto de Defensa Legal.

Bernedo Morales, Karen. 2011. "Mama quilla: los hilos (des) bordados de la Guerra - arpilleras para la memoria." Dissertation manuscript. Pontificia Universidad Catolica del Peru.

Buntnix, Gustavo, and Gabriela Germana. 2012. Exibition 'Éxodo, Llaqta Puchukay': historias de migraciones y violencia en las pinturas de Sarhua. Asociacion de Artistas Populares de Sarhua. Lima: Municipalidad de Lima.

Burt, Jo-Marie. 2007. Political Violence and the Authoritarian State in Peru: Silencing Civil Society. New York: Palgrave Macmillan.

Cánepa, Gisela. 2011. Imaginación visual y cultura en el Perú. Lima: Fondo Editorial de la Pontificia Universidad Católica del Perú.

CVR (Comisión de la Verdad y Reconciliación). 2003. Informe final de la comisión de la verdad y reconciliación. Tomo I-VIII. Lima: CVR.

CVR (Comisión de la Verdad y Reconciliación). 2004. Hatun willakuy: Versión abreviada del informe final de la comisión de la verdad y reconciliación, Perú. Lima: CVR.

Degregori, Carlos Ivan. 1990. Fatal Attraction: Peru's Shining Path. NACLA Report on the Americas. Lima: North American Congress on Latin America.

Degregori, Carlos Ivan and Pablo Sandoval. 2009. Antropología y antropólogos en el Perú: la comunidad académica de ciencias sociales bajo la modernización neoliberal (Vol. 33). Lima: Instituto de Estudios Peruanos.

Degregori, Carlos Ivan. 2000a. Discurso político, y violencia politica en sendero liminoso. Bulletin de l'institut francais d'études andines 29 (3): 493-513.

Degregori, Carlos Ivan. 2000b. La década de la antipolítica: Auge y huida de Alberto Fujimori y Vladimir Montesinos. Serie ideología y política. Lima: Instituto de Estudios Peruanos.

Degregori, Carlos Ivan. 2010. Qué difícil es ser dios: El partido comunista del Perú: Sendero luminoso y el conflicto armado interno en el Perú, 1980-1999. Lima: Instituto de Estudios Peruanos.

Degregori, Carlos Ivan. 2015. Heridas abiertas derechos esquivos. Derechos humanos, memorias y comisión de la Verdad y Reconciliación. Lima: Instituto de Estudios Peruanos.

Degregori, Carlos Ivan, and Elizabeth Jelin. 2003. Jamás tan cerca arremetió lo lejos: Memoria y violencia política en el Perú Serie ideología y política. Lima: Instituto de Estudios Peruanos Del Pino, Ponciano. 2003. Uchuraccay: memoria y representación de la violencia política en los Andes. In Jamás tan cerca arremetió lo lejos: memoria y violencia política en el Perú. Carlos Ivan Degregori, ed. Lima: Instituto de Estudios Peruanos

Del Pino, Ponciano. 2017. En nombre del gobierno. Lima: Siniestra y Universidad Nacional de El Altiplano.

Del Pino, Ponciano, and Caroline Yezer, eds. 2014. Las formas del recuerdo: Etnografias de la violencia politica en el Peru. Lima: Instituto de Estudios Peruanos. 
Dietrich, Martha-Cecilia. 2015. Discourses of violence or violent discourses? An audio-visual ethnography into the experience of violence in post-conflict Peru. Dissertation manuscript, University of Manchester.

Fangacio, Juan Carlos. 2018. Cómo Sarhua contó su lucha contra Sendero Luminoso a través del arte. El Comercio. https://elcomercio.pe/luces/arte/impreso-sarhua-mali-sendero-luminoso-artenoticia-492114 (accessed 19 May, 2019)

Figueroa Espejo, Mercedes. 2012. "Fue así como se fue" Álbum fotográfico familiar como espacio para representar y reconocer a las víctimas de la violencia en el Perú. Dissertation manuscript. Pontificia Universidad Catolica del Peru.

Gálvez Olaechea, Alberto G. 2012. Aún suenan tambores. Lima. https:// www.academia.edu/4218894/A\%C3\%BAn_Suenan_Tambores (accessed 19 May, 2019)

Gamundi, Cati Canayelles. 2010. "Ser mujer y revolucionaria.” (Master Thesis in Social Anthropology, University of Barcelona).

Golte, Jürgen and Ramon Pajuelo, Eds. 2012. Universos de memoria: aproximación a los retablos de Edilberto Jiménez sobre la violencia política. Estudios sobre memoria y violencia. Lima: Instituto de Estudios Peruanos.

González, Olga M. 2011. Unveiling Secrets of War in the Peruvian Andes. Chicago: University of Chicago Press.

Gorriti Ellenbogen, Gustavo. 1990. Sendero: historia de la guerra milenaria en el Perú. Lima: Editorial Apoyo.

Hamann, Marita, Santiago López Maguiña, and Gonzálo Portocarrero, Victor Vich. 2003. Batallas por la memoria: antagonismos de la promesa peruana. Lima: Instituto de Estudios Peruanos

Harvey, Penny. 1993. Ethnographic Film and the Politics of Difference: A Review of Film Festivals. Visual Anthropology Review, 9(1), 164-176.

Jiménez Quispe, Edilberto. 2010. Chungui: violencia y trazos de memoria Lima: IEP Ediciones

Lemlij, Moisés, and Luis Millones. 2004. Las tablas de Sarhua: arte, violencia e historia en el Perú. Lima: Sidea.

Levi, Primo. 1989. The Saved and the Drowned. London: Abacus.

Malek, Pablo. 2016. Enfoques, discursos y memorias: producción documental sobre el conflicto armado interno en el Perú. Lima: Grupo editorial Gato Viejo

Manrique, Nelson. 2002. El tiempo del miedo: la violencia política en el Perú, 1980-1996, Lima: Fondo Editorial del Congreso del Perú.

Manrique, Marie. 2014. Generando la inocencia: creación, uso e implicaciones de la identidad de «inocente» en los periodos de conflicto y posconflicto en el Perú. Bulletin de l'Institut Français d'Études Andines 43(1): 53-73.

Milton, Cynthia. 2014. Art from a Fractured Past. Memory and Turth-Telling in Post-Shining Path Peru. Durham, London, Duke University Press.

Poole, Deborah and Isaías Rojas Pérez. 2010. Memories of Reconciliation: Photography and Memory in Postwar Peru. Emisférica 7(2) After. https://hemisphericinstitute.org/en/ emisferica-72/7-2-essays/e72-essay-memories-of-reconciliation-photography-and-memory-inpostwar-peru.html 
Portocarrero, Gonzálo. 2012. Profetas del odio: Raices culturales y lideres de Sendero Luminoso, 2nd ed. Lima: Fondo Editorial de la PUCP.

Portugal, Andrea. 2008. Voices from the War: Exploring the Motivation of Sendero Luminoso Militants. CRISE working papers 57. https://www.qeh.ox.ac.uk/publications/voices-war-exploringmotivation-sendero-luminoso-militants (accessed 19 May, 2019).

Reátegui, Félix. 2018. La innecesaria reconciliación. http://idehpucp.pucp.edu.pe/opinion/lainnecesaria-reconciliacion-felix-reategui (accessed 19 May, 2019).

Soto Quispe, Heeder. (blog). https://heedersoto.wordpress.com/ (accessed 19 May, 2019)

Starn, Orin. 1995. Maoism in the Andes: The Communist Party of Peru-Shining Path and the Refusal of History. Journal of Latin American Studies 27 (2): 399-421.

Stern, Steve J., ed. 1999. Los senderos insólitos del Perú: Guerra y sociedad, 1980-1995. Lima: Instituto de Estudios Peruanos.

Theidon, Kimberly. 2010. Commissioning Truth, Constructing Silences: The Peruvian Truth Commission and the Other Truths of "Terrorists". In Mirrors of Justice: Law and Power in the PostCold War Era. K. M. C. a. M. Goodale, ed. Pp. 291-315Cambridge, New York, Cambridge University Press.

Tipe Sánchez, Víctor and Jaime Tipe Sánchez. 2015. Uchuraccay, el pueblo donde morían los que llegaban a pie. Lima: G7 Editores.

Ulfe, Maria E. 2014. Narrating Stories, Representing Memories: Retablos and Violence in Peru. In Art from a Fractured Past: Memory and Truth-Telling in Post Shining Path Peru. C.E. Milton, ed. Pp. 103126. Durham, NC: Duke University Press.

Ulfe, Maria E. 2017a. Arte y memoria o cuándo lo cultural se transforma en una plataforma de hacer política. In Arte y Antropología. Estudios, encuentros y nuevos horizontes. Giuliana Borea, ed. Pp. 267 - 280. Lima: Fondo editorial de la Pontificia Universidad Católica del Perú.

Ulfe, Maria E. 2017b. Dicen que el cóndor da vueltas, buscando... Tres relatos visuales sobre el conflicto armado interno peruano. In El Perú desde el cine. Plano contra plano. Liuba Kogan, Julio Villa and Guadalupe Pérez Recalde, eds. Pp. 115 - 128.Lima: Universidad del Pacífico.

Valenzuela Marroquin, Manuel Luis. 2011. Subalternidad y violencia política en el teatro peruano. El ingreso del campesino como referente de cambio. Alteridades 21 (41). Pp. 161-174

\section{Films discussed}

Aredondo, Teresa, dir. 2012. Sibila. Casimusicos Cine, Fondo de Fomento Audiovisual, CORFO (production), $94 \mathrm{~min}$.

Bernedo, Karen, dir. 2005. Tránsito a la Memoria. Bernedo (production), 7.34 min.

Bernedo, Karen, dir. 2011. Mamaquilla, Hilos (des)bordados de la Guerra. Tesis de Maestría en Antropología Visual, Karen Bernedo (production), 26.40 min.

Cárdenas, Alejandro, dir. 2005. Alias Alejandro. Sabotage Films (production), 93 min.

Cárdenas-Amelio, Alejandro, dir. 2005. Alias Alejandro. Sabotage Films, ZDF (production), 93min. Degregori, Luis Felipe, dir. 2010. Chungui, Horror sin Lágrimas. Buenaletra (production), 61 min. Dietrich, Martha-Cecilia, dir. 2015. Entre Memorias. RAI Film distribution, $34 \mathrm{~min}$.

Durand, Alberto, dir. 1999. Coraje. Agua Dulce Films. 112min. 
Durant, Alberto, dir. 1991. Alias 'La Gringa'. Channel Four Films, Instituto Cubano del Arte e Industrias Cinematográficos (ICAIC), Perfo Studio, Televisión Española (TVE) (production), 92 $\min$.

Gálvez, Héctor, and Carlos Cárdenas, dir. 2008. Lucanamarca. TV y Cultura (production), 52 min. González, Amanda, dir. 2011. La cantuta en la boca del diablo. TV Cultura (production), 129 min. Lombardi, Francisco, dir. 1985. La ciudad de los perros. Inca Film (production), 135 min. Lombardi, Francisco, dir. 1988. La Boca del lobo. Inca Film, New People's Cinema, Tornasol Films (production), $116 \mathrm{~min}$.

Meyer, Jorge, dir. 2007, Lágrimas de Wayronco. Meyer Films, Dandovueltas (production), 96 min. Ortega Matute, Palito, dir. 1997. Dios tarda pero no olvida. Roca Films, Fox Perú Producciones (production), 110min.

Peirera del Mar, Nilo, dir. 1990. Ni con dios, ni con el diablo. Urpi Cine Producciones (production), 89 $\min$.

Perry, Ellen, dir. 2005. La caída de Fujimori, Cinema Libre Studio, Stardust Productions, Roo Films (production), $83 \mathrm{~min}$.

Robin, Valérie, and Nicolas Touboul, dir. 2007. Sur le Sentier the la Violence. Robin, Toubol, IRD (production), $60 \mathrm{~min}$.

Soto, Heeder, dir. 2015. Caminantes de la Memoria. Fetzer Institute (production), $73.52 \mathrm{~min}$.

Wiström Mikael, dir. 2011. Tempestad en los Andes. Casablanca Cine, Mänharen Film \& TV AB

(production), $100 \mathrm{~min}$.

Yates, Pamela, dir. 2005. Estado de miedo. Skylight Pictures (production), $94 \mathrm{~min}$.

\section{Websites}

"Museo Itinerante Arte por la Memoria" https://arteporlamemoria.wordpress.com/ (accessed 19 May, 2019)

\section{NOTES}

1. Maestría en Antropología Visual, Escuela de posgrado, PUCP.

2. For more information, see: http://posgrado.pucp.edu.pe/maestria/antropologia-visual/.

3. The MRTA was found responsible for 1.8 per cent of inflicted deaths during the conflict.

4. The Shining Path's ideology was called Pensamiento Gonzalo (Gonzalo Thought).

5. A number of measures were introduced and supported by different governments. In 2006, a program on financial and symbolic reparations was launched. There have been different judiciary trials against perpetrators and there are several places and monuments for memory like the Lugar de la Memoria, de la Tolerencia e Inclusión Social. On December $24^{\text {th }}$ 2017, President Pedro Pablo Kuczynski granted pardon to Alberto Fujimori who received a sentenced for corruption scandals and human rights violations. Réategui (2018) describes this moment as "the kidnapping of memory and its languages".

6. The 1615 letter was entitled 'New Chronicles and Good Governance'.

7. In the current context of Fujimori's pardon, the Sarhua tablas of the collection Piraq Causa are in the midst of a political debate after a member of congress accused the artists of "apologia de 
terrorismo" (apology of terrorism). For instance, see: Fangacio 2018 https://elcomercio.pe/ luces/arte/impreso-sarhua-mali-sendero-luminoso-arte-noticia-492114.

8. Centre for Agricultural Development-Ayacucho.

9. See for example: La ciudad de los perros by Francisco Lombardi (1985), Boca del lobo by Francisco Lombardi (1988), Ni con dios, ni con el diablo by Nilo Peirera del Mar (1990), Alias la gringa by Alberto Durant (1991), Dios tarda, pero no olvida by Palito Ortega Matute (1997), Coraje by Alberto Durand (1999), among others.

10. Alias Alejandro by Alejandro Cardenas (2005), Tempestad en los Andes by Mikael Wiström (2011) and Sibila by Teresa Arredondo (2012) are three films that share the idea of traveling as a metaphor for storytelling, (see Ulfe 2017b).

11. Estado de miedo by Pamela Yates (2005), La caída de Fujimori by Ellen Perry (2005), Lágrimas de Wayronco by Jorge Meyer (2007), and La cantuta en la boca del diablo by Amanda González (2011), among others.

12. See Bernedo 2015 https://imagenespaganas.lamula.pe/2015/03/30/accomarca-vive/ kbernedo/.

13. Asociación Nacional de Familiares de Secuestrados, Detenidos, y Desaparecidos del Perú (National Association of Relatives of the Kidnapped, Imprisoned, and Disappeared in Peru)

14. There were three women on the panel of jurors: see https://raifilm.org.uk/judges/.

\section{ABSTRACTS}

In recent years, Peruvian social anthropology has seen a rising production of audio-visual and artistic works within the discipline, ranging from written analyses that incorporate arts and crafts (Bernedo 2011; González 2011; Ulfe 2014; Del Pino and Yezer 2014) to photographic projects (Poole 2010; Figueroa 2012), nonfiction films (Dietrich 2015; Malek 2016), virtual museums and online blogs. In this article, we identify the paths visual anthropology (VA) is taking in the country in order to analyse how these forms are creatively reinventing social anthropology as an analytical and methodological field. Furthermore, we take this opportunity to discuss the valuable, but internationally unknown, works of audio-visual anthropologists in and of Peru.

Ces dernières années, l'anthropologie sociale péruvienne a connu une production croissante d'œuvres audiovisuelles et artistiques au sein de la discipline, allant des analyses écrites qui incorporent les arts et métiers (Bernedo 2011 ; González 2011 ; Ulfe 2014 ; Yezer et Del Pino 2014) aux projets photographiques (Poole 2010 ; Figueroa 2012), films non fictifs (Dietrich 2015; Malek 2016), aux musées virtuels comme et aux blogs en ligne. Dans cet article, nous identifions les orientations prises par l'anthropologie visuelle (AV) dans le pays afin d'analyser comment ces formes réinventent de manière créative l'anthropologie sociale comme champ analytique et méthodologique. De plus, nous profitons de l'occasion pour discuter des travaux précieux, mais internationalement inconnus, d'anthropologues de l'audiovisuel au Pérou et du Pérou.

Recientemente, la antropología social peruana ha vivido un incremento en la producción de trabajos audiovisuales y artísticos al interior de la disciplina, que van desde los análisis escritos que incorporan artes y oficios (Bernedo 2011; González 2011; Ulfe 2014; Yezer and Del Pino 2014) hasta proyectos fotográficos (Poole 2010; Figueroa 2012), películas de no-ficción (Dietrich 2015; Malek 2016), museos virtuales y blogs en línea. En este artículo, identificamos las rutas que la 
antropología visual está tomando en el país con el fin de analizar cómo estas formas están reinventando creativamente a la antropología social como un campo analítico y metodológico. Aún más, tomamos esta oportunidad para discutir los valiosos, pero desconocidos internacionalmente, trabajos de antropólogos audiovisuales en y sobre Perú.

\section{INDEX}

Mots-clés: anthropologie visuelle, ethnographie multimodale, mémoire, Pérou post-conflit Keywords: visual anthropology, multimodal ethnography, memory, post-conflict Peru

Palabras claves: antropología visual, etnografía multimodal, memoria, Perú del postconflicto

\section{AUTHORS}

\section{MARTHA-CECILIA DIETRICH}

University of Bern

martha-cecilia.dietrich@anthro.unibe.ch

Martha-Cecilia Dietrich completed her PhD in Social Anthropology with Visual Media at the Granada Centre for Visual Anthropology at the University of Manchester (2015). She is currently a lecturer and post-doctoral researcher at the Department of Social Anthropology at the University of Bern. Her work is situated in the fields of political anthropology, memory in postconflict settings and filmmaking as research method.

\section{MARÍA EUGENIA ULFE}

Pontificia Universidad Católica del Perú mulfe@pucp.edu.pe

María Eugenia Ulfe is a Peruvian Anthropologist, $\mathrm{PhD}$ in Human Sciences/Anthropology at the George Washington University (Washington DC, 2005) and MA in the Arts of the Americas, Oceania, and Africa at the University of East Anglia (United Kingdom, 1995). Associate Professor at the Department of Social Sciences and Director of the Master Program in Anthropology and the Master Program in Visual Anthropology at the Pontificia Universidad Católica del Perú. Her work focuses on memory, creative culture, violence, and visual Anthropology. 